
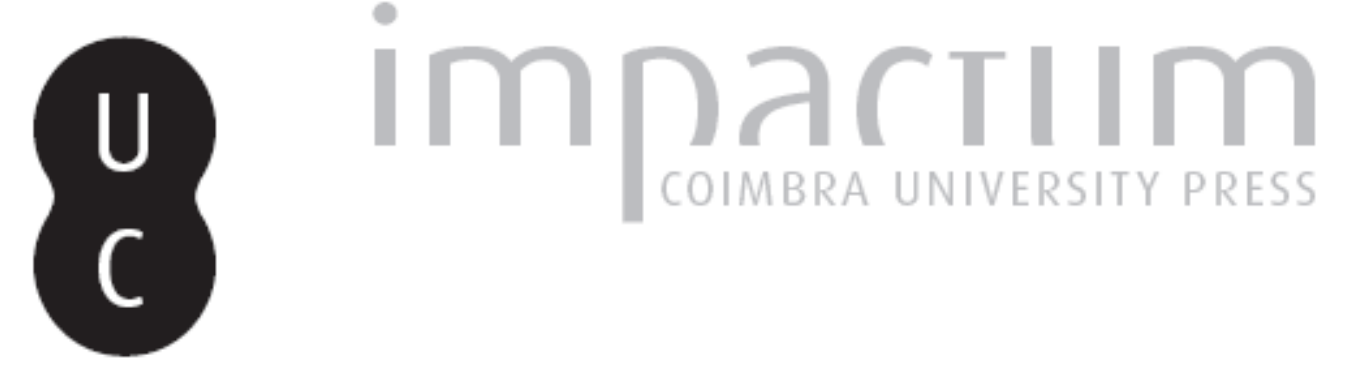

\title{
[Recensão a] CHRISTIAN LAES et JOHAN STRUBBE (2014), Youth in the Roman Empire. The Young and the Restless Years?
}
Autor(es):
Rodrigues, Nuno Simões
Publicado por: Centro de História da Universidade de Lisboa
URL
persistente:
URI:http://hdl.handle.net/10316.2/38939
DOI:
DOI:http://dx.doi.org/10.14195/0871-9527_24_15

Accessed : $\quad$ 26-Apr-2023 05:36:53

A navegação consulta e descarregamento dos títulos inseridos nas Bibliotecas Digitais UC Digitalis, UC Pombalina e UC Impactum, pressupõem a aceitação plena e sem reservas dos Termos e Condições de Uso destas Bibliotecas Digitais, disponíveis em https://digitalis.uc.pt/pt-pt/termos.

Conforme exposto nos referidos Termos e Condições de Uso, o descarregamento de títulos de acesso restrito requer uma licença válida de autorização devendo o utilizador aceder ao(s) documento(s) a partir de um endereço de IP da instituição detentora da supramencionada licença.

Ao utilizador é apenas permitido o descarregamento para uso pessoal, pelo que o emprego do(s) título(s) descarregado(s) para outro fim, designadamente comercial, carece de autorização do respetivo autor ou editor da obra.

Na medida em que todas as obras da UC Digitalis se encontram protegidas pelo Código do Direito de Autor e Direitos Conexos e demais legislação aplicável, toda a cópia, parcial ou total, deste documento, nos casos em que é legalmente admitida, deverá conter ou fazer-se acompanhar por este aviso.

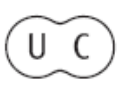




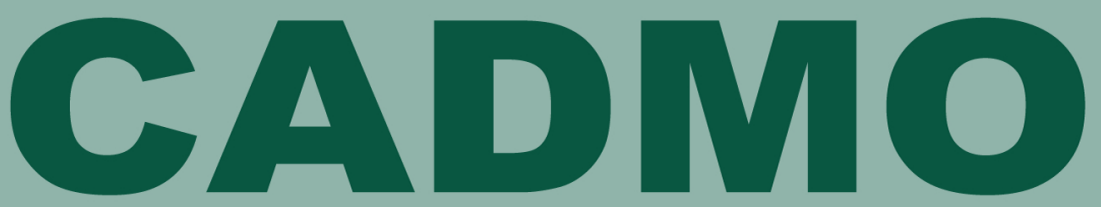

Revista de História Antiga

\section{Centro de História da Universidade de Lisboa}

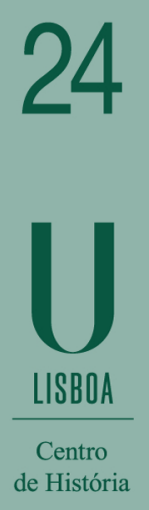

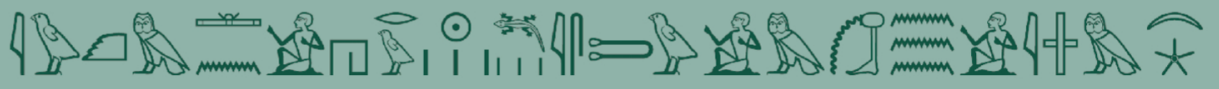

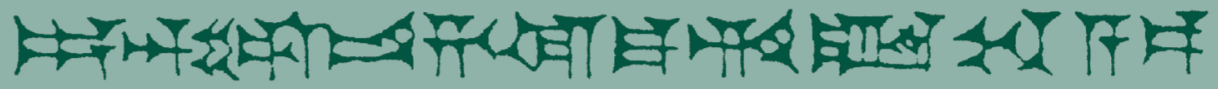
MHNIN AEI $\Delta$ E $\Theta E A ~ \Pi H \Lambda H I A \Delta E \Omega$ 
em comparação com a sua quase insignificância na sociedade grega. É sublinhado o intuito do estudo: realçar a autonomia política das duas mulheres visadas, não como subordinadas a Octaviano e António, mas como feminae politicae.

Esta obra é um contributo assinalável para a história das elites femininas romanas. Seria, no entanto, impossível que numa obra desta envergadura não houvesse algumas pequenas observações a assinalar. Poderiam ter sido discutidos com maior pertinência a origem, influência e ambiente da produção das fontes citadas. Lamentamos, igualmente, a quase completa ausência do testemunho de Flávio Josefo, fonte essencial para compreender o período de estadia de António no Próximo Oriente e, principalmente, no tratamento da imagem de Cleópatra VII. Seria também desejável que o extenso corpus numismático fornecido na obra acompanhasse o texto produzido (e.g. pp.35-36). Como complemento a este trabalho, seria importante uma aproximação ao estudo da terceira mulher de António, Fúlvia, baseado em dois tópicos: os traços retóricos do comportamento de uma matrona romana (Octávia vs Fúlvia) e os paradigmas de alteridade (Fúlvia vs Glafira). Notamos a ausência do testemunho de Sen. Suas. 1.6. (pp.78-79). Na p.174, o autor propõe analisar as deserções de Planco e Aenobarbo, quando, porém, analisa as de Planco e Marco Tito.

No seu conjunto, o livro em recensão reveste-se do maior interesse e importância para o estudo do uso da propaganda como História. $\mathrm{O}$ tratamento de que dispõem Octávia (normalmente subvalorizada no tratamento da elite feminina romana no século I a.C./d.C.) e Cleópatra VII constitui-se como uma mais-valia para os gender studies, tanto pela aposta na temática, como pela abordagem original.

João Paulo Valério

CHRISTIAN LAES et JOHAN STRUBBE (2014), Youth in the Roman Empire. The Young and the Restless Years?, Cambridge, Cambridge University Press, 256 pp. ISBN 978-1-107-04888-1 (hardback, £60.00), 978-1-107-62672-0 (paperback).

Este livro é uma versão inglesa de um original publicado em neerlandês, em 2008, Jeugd in het Romeinse Rijk: Jonge jaren, wilde haren?, que segue os trabalhos e investigação desenvolvida por $\mathrm{E}$. 
Eyben, no âmbito dos estudos sobre a juventude na Roma Antiga. Com efeito, como têm demonstrado os seus trabalhos, C. Laes é um dos académicos que mais se tem dedicado a esta problemática, no seguimento de Eyben. O livro agora publicado em parceria com J. Strubbe vem confirmar a qualidade dos estudos previamente publicados por Laes, mas também trazer novas abordagens e perspectivas que foram reconhecidas pela editora de Cambridge, ao ponto de nos oferecer esta versão em língua inglesa.

Um dos méritos deste volume, que destacamos desde já, é o facto de os seus autores terem decidido apresentar como capítulo introdutório uma síntese que diz respeito sobretudo à teoria subjacente à problemática estudada. O que se deve entender por «juventude»? Assim, Laes e Strubbe não escapam à complexidade da tarefa e propõem a sua análise, incluindo teses e perspectivas de autores tão importantes quanto Margaret Mead, Philippe Ariès, Lawrence Stone e o próprio Emiel Eyben. Cada um destes autores trabalhou em domínios distintos, da Antropologia à História, da História Antiga e Medieval à História Moderna, mas todos com a preocupação comum de analisar a problemática da juventude. Este capítulo, por si só, teria valido esta publicação, dada a sistematização e síntese apresentadas.

Os restantes doze capítulos do livro centram-se em análises concretas do tema da juventude na Roma Antiga, levando em conta questões tão pertinentes quanto as ideias de «minoridade» e de «maioridade» (as tão celebrizadas «idades do homem»), terminologia, rituais de passagem, questões médicas, educação, sociabilidade, comportamentos e casamento. É ainda incluída uma importante rubrica sobre as perspectivas pré-cristãs e cristãs do tema, sendo esta da maior importância, uma vez que o assunto é diacrónico e por isso torna-se relevante perceber as rupturas, se as há, ou as continuidades.

Uma bibliografia final e um índice remissivo contribuem também para a qualidade do volume. Mas seria pertinente, ou mesmo desejável, a existência um índice de passos citados, dado que a investigação de Laes e Strubbe se centra fortemente em fontes literárias. De qualquer modo, este é mais um valioso contributo para o estudo da história social e das mentalidades da Roma Antiga.

Nuno Simões Rodrigues 